\title{
PAPÍron VAgy ELEKTRONIKUSAN, AVAGY AZ E-PEREK JELENe ÉS JÖVŐJE
}

\section{Farkas Henrietta Regina ${ }^{1}$}

Az informatika óriási fejlődésen ment át az elmúlt évtizedekben, és ma már az élet minden területén használhatjuk a számítógépeket. Ez a változás utolérte az állami szervezetrendszert is, amelyet ösztönöznek a digitalizálódás előnyei, az ügyfelek igényei. A fejlődéssel igyekszik lépést tartani az igazságszolgáltatási rendszer is, és az elmúlt egy évben jelentős változásokat figyelhetünk meg a bíróságok és az ügyfelek közötti kommunikáció terén. A legnagyobb előrelépés 2016. július 1-jétől következik be, amikor a jogi képviselők és a gazdálkodó szervezetek számára kötelezővé válik az elektronikus kommunikáció a bíróságokkal. De vajon fel vannak-e készülve erre a változásra a szereplők és mindez hogyan hathat a bíráskodásra, a bíróságok munkájára?

\section{Az elektronikus kommunikáció szabályai a polgári és a büntető eljárásokban}

Az elektronikus kommunikáció terén jól jelzi a változást a Polgári perrendtartásról szóló törvény $^{2}$ (továbbiakban: Pp.) XXVIII. fejezete, amely a bíróság és az ügyfelek, illetve az eljárás egyéb résztvevői közötti elektronikus kapcsolattartást szabályozza. A polgári eljárásokban a változás még 2013. január 1-jén indult el, amikor lehetővé vált a törvényszék elsőfokú hatáskörébe tartozó ügyekben a beadványokat elektronikus formában is benyújtani. A további fejlődést azonban a 2015-2016-os év jelentette, 2015. július 1-jétől ugyanis minden bíróságon lehetőség nyílt az elektronikus kommunikációra. ${ }^{3}$ 2016. június 30. napjáig volt egy átmeneti időszak, amely alatt választhattak a gazdálkodó szervezetek és a jogi képviselők, hogy élnek-e az elektronikus kommunikáció lehetőségével, ezután viszont kizárólag elektronikus úton nyújthatják be beadványaikat. ${ }^{4}$

A korábbi tervek szerint mindez már 2016. január 1-jétől megvalósult volna, azonban a különböző szereplők nem tudtak felkészülni a változásra. Mindehhez természetesen nemcsak arra van szükség, hogy a bíróság informatikai rendszere készen álljon az újításra, hiszen a jogi képviselőknek vagy más hatóságoknak ugyan csak fel kell készülniük, ami egyrészt szoros együttmüködést kíván a szereplőktől, másrészt jelentős költségekkel járhat.

Ezt mutatja például az a megállapodás is, amely az Egri Járásbíróság és az egyik ügyvédi iroda között született. Ennek keretében ha iratok kerülnek elektronikus formában megküldésre, telefonon jeleznek egymásnak az érintettek annak érdekében, hogy megfigyeljék az egymás közötti kommunikáció közvetlenségét, gördülékenységét.

\footnotetext{
${ }^{1}$ Farkas Henrietta Regina, az Egri Járásbíróság bírósági fogalmazója, a DE-ÁJK PhD hallgatója

2 1952. évi III. törvény a polgári perrendtartásról.

3 1952. évi III. törvény a polgári perrendtartásról, 394/B-C. §, 321/A. § (3) bek.

4 1952. évi III. törvény a polgári perrendtartásról, 397/I. §.
} 
Kisebb léptékü fejlődést láthatunk a büntetőeljárásoknál, ami nyilvánvalóan az eljárás természetéből fakad. 2013. január 1-jétől az elektronikus kommunikáció már ezen a területen is megjelenik, amely elsősorban a hatóságok közötti kommunikációra vonatkozik. A Büntetőeljárásról szóló törvény ${ }^{5}$ (továbbiakban: Be.) tavaly májusi módosításával viszont a fejlődés újabb állomásához érkeztünk, ugyanis a törvény a polgári perekhez hasonlóan 2015. július 1-jétől lehetővé teszi az ügyféllel való elektronikus kapcsolattartást. Ez azonban nagyon szük körre korlátozódik, és a Be. kizárólag a terhelt védője számára engedi meg az összbüntetésbe foglalás és az utólagos összbüntetésbe foglalás iránti indítvány, valamint ezen indítvány visszavonásának elektronikus benyújtását. ${ }^{6}$

\section{Az elektronikus kommunikáció megvalósulási formája: az ÜKM}

A jogszabályok természetesen mit sem érnek azok megvalósulása nélkül. A fentebb ismertetett szabályozás végrehajtása az ügyfélkapcsolati modulon (ÜKM) keresztül történik, amely elérése 2015. július 1. napjától lehetséges. Ezen kommunikációs eszköz müködéséhez ügyfélkapura van szükség, amelyen az ügyfelek láthatják az Országos Bírósági Hivatal hivatali kapuját. A hivatali kapu útján továbbítják elektronikus beadványaikat, amelyek megjelennek a címzett bíróság E-postafiókjában. A változáshoz a jogszabályok is igazodtak, hiszen a kézbesítésnek ugyanúgy szabályszerüen kell történnie mint a papír alapú kommunikáció esetében. A bírósági iratok az esetek legnagyobb részében tértivevény útján kerülnek kézbesítésre. A tértivevényen pontosan látszik, ki, mikor vette át az adott okiratot, így füződhetnek jogkövetkezmények az iratok kézbesítéséhez. Elektronikus kommunikáció esetén elektronikus tértivevényröl beszélünk. Az elektronikus tértivevény egy fájl, amelyet a bíróság küld meg az ügyfélnek. Ezt a dokumentumot meg kell nyitni 5 munkanapon belül a szabályszerü kézbesítéshez. Amennyiben ezt nem teszi meg az adott fél, beáll a kézbesítési vélelem a Pp. szabályai szerint, és a bíróság kézbesítettnek tekinti az iratot. ${ }^{7}$

Az ÜKM július 1-je előtt nem volt túl népszerü, az Egri Járásbíróságon például elindulása óta mindössze néhány esetben fordult elö, hogy ezen a rendszeren keresztül indult volna peres eljárás. A Törvényszéken már gyakoribb volt, hogy iratok elektronikus formában érkeztek, különösen ha nagy terjedelmüek voltak vagy ha a jogi képviselő nem helyi volt.

\section{Az elektronikus irat sorsa}

Kérdés lehet azonban, milyen mértékü lesz most már az elektronizáció a peres eljárásokban. Az elektronizáció egyelőre részleges lesz, így amikor egy irat megérkezik a bírósághoz, az kinyomtatásra kerül, hiszen a bíró minden esetben papír alapon kapja meg. A kinyomtatott példányok száma a felek számától függ, illetve attól, hogy valamely fél elektronikus kommunikációra kötelezett-e. Ha ugyanis valamely fél gazdálkodó szervezet, számára akkor is elektronikusan kézbesítenek, ha ő az alperes. Amennyiben viszont az alperes természetes személy és nem választja az elektronikus kommunikáció lehetőségét, akkor számára papíron kell megküldeni az iratokat, valamint papír alapú beadványait be kell szkennelni, a felperessel

\footnotetext{
${ }^{5}$ 1998. évi XIX. törvény a büntetőeljárásról.

${ }^{6}$ 1998. évi XIX. törvény a büntetőeljárásról, Be. 69/A-D. §§.

${ }^{7}$ 1952. évi III. törvény a polgári perrendtartásról, 394/H. § (8) bek.
} 
ugyanis már csak elektronikusan tartható a kapcsolat. Az elektronikus kommunikációra kötelezett felek, illetve akik ezt a kapcsolattartási formát választották, már nem térhetnek át a papír alapú kommunikációra. Amennyiben később mégis így nyújtanának be egy okiratot, annak a per állásától függően többféle következménye lehet. A beadvány ilyen esetben hatálytalan lesz, vagyis úgy kell rá tekintenie a bíróságnak, mintha nem is létezne, jogkövetkezmény nem füződhet hozzá. Ezen túlmenően a keresetlevél idézés kibocsátása nélküli elutasítása, valamint pénzbírság kiszabása is következménye lehet.

\section{Az elektronikus kommunikáció jövője?}

Kérdésként merülhet fel, hogy más országok merre tartanak ezen a területen? Például Ausztriában ha hivatalos okiratot kézbesítenek, akkor először erről értesítik az adott felet. Ez az értesítés e-mailben, telefonon vagy sms-ben történik. Az ügyfél egy linken keresztül elektronikusan kapja meg a levelet, de ha kéri, a postahivatal kinyomtatja és papíron küldi meg. Finnországban majdnem teljesen automatizált a sommás eljárás, és a papír alapú kommunikáció csak szük körben van jelen, de hasonlóan automatizált Németországban a fizetési meghagyásos eljárás. A legmeglepőbb példa azonban véleményem szerint az az eset, amikor Ausztráliában egy bíró engedélyezte az egyik fél számára az okiratok kézbesítését a facebookon keresztül. Ennek természetesen feltételei is voltak, így más kézbesítési lehetőség nem állt rendelkezésre és a facebook-profil bizonyíthatóan a címzettekhez tartozott. A legjellemzőbbek azonban a világon elsősorban az ún. hibrid eljárások, amikor részben papír alapon, részben elektronikusan történik a kommunikáció. ${ }^{8}$

\section{A digitalizálódás hatásai a bírósági munkára}

A jogalkotó szándéka mindezzel az lenne, hogy a bírósági eljárások és a teljes munkafolyamat elektronikusan valósuljon meg. Ez azt jelentené, hogy elektronikus formában tartják a felek a kapcsolatot a bírósággal, és adott esetben a tárgyalások videokonferencia útján bonyolódnának le. Álláspontom szerint ezt a folyamatot jelzi hazánkban a Pp. és a Be. fentebb ismertetett szabályozása, valamint a Pp. 2015. december 4-től hatályos a zártcélú távközlő hálózatról szóló része, ${ }^{9}$ illetve az azt végrehajtó és részletszabályairól rendelkező új IM rendelet $^{10}$ is. $^{11}$

A cél az elektronizációval a peres eljárások gyorsítása, időszerüségük javítása, a költségek csökkentése lenne. A digitalizálódásnak számos előnye van, ezek közül az egyik legszembetünőbb a peres ügyek lefolytatásának gyorsulása lehet. Gyorsabbá válik az ügymenet mind a belső munkafolyamatok terén, mind az ügyfelekkel történő könnyebb kommunikáció révén. Ez növeli a bíráskodás hatékonyságát, csökkenti az ügyterhet, a perek rövidebb ideig tartanak. Az elektronizálódással sok költséget takaríthatunk meg, hiszen ha

\footnotetext{
${ }^{8}$ HARSÁGI Viktória: Kézbesítés a polgári jogvitákban határok nélkül, HVG-Orac Lap- és Könyvkiadó Kft., Budapest, 2010., 111-113., 118., 120-121.

9 1952. évi III. törvény a polgári perrendtartásról, XXVIII/A. fejezete.

${ }^{10}$ 3/2016. (II. 22.) IM rendelet a polgári eljárásban a tárgyalás, valamint a személyes meghallgatás zártcélú távközlő hálózat útján történő megtartásáról.

${ }^{11}$ A Be.-ben már sokkal korábban, 2003 óta lehetőség van erre. Lásd: Be. 244/A-D. §, a tárgyalás zártcélú távközlő hálózat útján történő megtartásáról szóló 22/2003. (VI.25.) IM rendelet.
} 
nem kell másolni és nyomtatni, akkor megspórolható a papír, a tinta és a nyomtató használatának költsége is. Az iratok tárolása szempontjából szintén számos előnye van a digitalizálódásnak, hiszen nincsen szükség irattárra az ügyiratok biztonságos őrzése érdekében. Jelenleg nagy gondot okoz ugyanis az iratok őrzése: nagyon sok helyet foglalnak, fokozottan tüzveszélyesek, a papírok pedig sérülékenyek. Ezen problémákra megoldást jelenthet az elektronikus fejlödés, hiszen így az iratok elektronikus irattárba kerülnek.

De vajon mindez tényleg így lesz? Július 1-jétől mind papír alapon, mind elektronikusan kezelni kell majd az okiratokat abban az esetben is, ha mindkét fél elektronikus kommunikációra kötelezett vagy ezt választja, a bírósági akta ugyanis továbbra is papír alapú marad. Ez azt jelenti, hogy a papíron érkezett iratokat a bíróságnak minden esetben szkennelni kell, az elektronikusokat pedig nyomtatni. Ez feltehetően az iratkezelést rendkívül nehézkessé fogja tenni, és a bíróságokra jelentős többletköltséget, míg a kezelöirodák dolgozóira nagy terhet fog róni. Egy-egy okirat vagy melléklet több száz oldalas is lehet, aminek a nyomtatása rendkívül költséges, míg szkennelése sok idő. Csak a jelenleg több ezer folyamatban lévő devizaperekre gondoljunk, ahol a keresetlevél olyan mellékletei mint a kölcsönszerződés, az ÁSZF, az üzletszabályzatok és a hirdetmények önmagukban többtíz oldalasak. Kérdés egyelöre, hogy a kezelőirodák hogyan fogják bírni a többletfeladatokat, amelyek talán a peres eljárások gyorsulása helyett éppen azok lassulását, az iratok áramlásának nehézkessé válását okozhatják.

Az előnyök mellett legalább ugyanannyi hátrányát is megnevezhetjük a digitalizálódásnak. Talán a legfontosabb hátránya, hogy müszaki feltételekhez kötött, így ha meghibásodik a számítógép, szoftverhiba történik vagy áramszünet lesz, a munka gyakorlatilag leáll a bíróságokon. Mivel egyre több adat kerül kezelésre elektronikusan, ezért fontos kérdés a személyes adatok védelme, de felmerülhet a vírusfertőzés veszélye is, amely nemcsak a bíróságokat, hanem az ügyfeleket is érintheti. Az informatika sokszínüségéből, illetve az informatikai megoldások egyszerüségéből szintén eredhetnek problémák, így a véletlen törlés vagy az elektronikus adat elvesztésének veszélye is fennáll. Felmerülhet a dokumentumok hitelessége és sérthetetlensége megőrzésének kérdése, amelyet a bíróságnak biztosítani kell, de problémás lehet a különböző formátumú fájlok továbbítása, amelyek megnyitásához más és más szoftverre van szükség, illetve aggályokat vethet fel a kézbesítés bizonyíthatósága, de nem utolsó sorban beszélnünk kell az egészségügyi kockázatokról is.

Nagy változás előtt állunk tehát július 1-jétől, ettől az időponttól kezdve ugyanis a jogi képviselők és a gazdálkodó szervezetek kizárólag elektronikus formában tarthatják a kapcsolatot a bírósággal. Számos előnye nevezhető meg a digitalizálódásnak, amelyek egyelöre csak elméletben léteznek, és több hátrányt is felsoroltunk, amelyeknek reális veszélyei állnak fenn. A valós következményeket azonban csak július 1-jét követően figyelhetjük meg, és kiderülhet van-e létjogosultsága a párhuzamos iratkezelésnek, vagy döntenünk kell valamely kommunikációs forma kizárólagossága mellett. 